\title{
Thermal loads of a piston in a diesel engine during startup
}

\begin{abstract}
The paper presents the issue of thermal loads of a piston in a combustion engine with direct injection during startup. Theoretical assumptions have been described as well as the programme of engine test bed and simulation research based on the previous results of tests in the low temperature test chamber. Differences taking place in the piston thermal loads have been discussed as well as their influence on an efficient startup at low ambient temperatures.
\end{abstract}

Key words: combustion engine, start-up

\section{Obciążenia cieplne tloka silnika wysokoprężnego podczas rozruchu}

\begin{abstract}
W artykule przedstawiono problematykę obciażeń cieplnych tłoka silnika spalinowego o wtrysku bezpośrednim podczas rozruchu. Opisano założenia teoretyczne oraz program badań hamownianych i symulacyjnych skonstruowany na podstawie wcześniejszych wyników badań w komorze niskich temperatur. Omówiono różnice występujace w obciażeniach termicznych tłoka i ich wplyw na skuteczny rozruch w niskich temperaturach otoczenia.
\end{abstract}

Słowa kluczowe: silnik, rozruch w niskich temperaturach

\section{Introduction}

Piston combustion engines are currently a common drive for different types of vehicles and machines. The modernisation and introduction of new construction and operating solutions of combustion engines very often occurs with the same or relatively unchanged design solutions, or at least with the basic geometrical elements of the main engine parts unchanged. This is connected with the increase of mechanical and thermal loads on parts surrounding the combustion chamber.

Thermal loads are one of the factors that influence the strength of elements. They can be considered as:

- thermal loads of the combustion chamber,

- thermal loads of the engine parts that surround the combustion chamber.

The assessment of the thermal load of a piston can be made based on the analysis of its thermal fields. Calculations of thermal loads in steady states have been sufficient so far. At unsteady thermal loads, the temperatures in particular points of a piston are variable in time.

The engine start is an unsteady state of the engine operation. During the engine startup, its operating parameters and the heat exchange are changed in time. Then, an unsteady heat exchange takes place, depending on time. During a cold start, particularly at low ambient temperatures, the engine is not heated, and the parts surrounding the combustion chamber are subject to sudden temperature surges.

Getting to know the piston temperature distribution not only during the normal engine operation but also during its unsteady operation is very essential. It is important to ensure an optimum - as far as the utilitarian issues are concerned - compatibility of operation and co-operation of elements within a wide range of engine operating conditions, both steady and transient (unsteady) ones. It is necessary to design a piston and manufacturer it from such materials that a

\section{Wstęp}

Tłokowe silniki spalinowe są obecnie powszechnym źródłem napędu różnego rodzaju pojazdów, maszyn i urządzeń. Modernizacja oraz wprowadzanie nowych rozwiązań konstrukcyjno-eksploatacyjnych silników spalinowych odbywa się bardzo często przy tych samych lub nieznacznie zmienionych rozwiązaniach konstrukcyjnych, albo niezmienionych zasadniczych wymiarach geometrycznych głównych części silnika. Wiąże się to ze zwiększeniem obciążeń mechanicznych i cieplnych części otaczających komorę spalania.

Obciążenia cieplne są jednym z czynników, które wpływają na wytrzymałość elementów. Można rozpatrywać je jako:

- obciążenia cieplne komory spalania,

- obciążenia cieplne części silnika otaczających komorę spalania.

Ocenę obciążenia cieplnego tłoka można uzyskać na podstawie analizy jego pól temperatur. Dotychczas wystarczające były obliczenia obciążeń cieplnych w stanach ustalonych. Przy nieustalonych obciążeniach cieplnych, temperatury w poszczególnych miejscach tłoka zmieniają się w czasie.

Rozruch silnika jest stanem nieustalonej pracy silnika. W czasie rozruchu silnika jego parametry pracy oraz wymiana ciepła zmieniają się w miarę upływu czasu. Występuje wtedy nieustalona wymiana ciepła, zależna od czasu. Podczas zimnego rozruchu, zwłaszcza w niskich temperaturach otoczenia, silnik jest nienagrzany, a części otaczające komorę spalania poddane są nagłym przyrostom temperatury.

Poznanie rozkładu temperatury tłoka, nie tylko w czasie normalnej pracy silnika, ale też w czasie jego nieustalonej pracy jest bardzo istotne. Ważne jest zapewnienie optymalnej, ze względów użytkowych, zgodności pracy i współpracy elementów w szerokim zakresie warunków pracy silników i 
correct operation is ensured. The piston cannot be subject to premature wear, or damage, and in the general understanding, it cannot cause a faulty engine operation. It must be characterised by high resistance to mechanical and thermal loads as well as reliability and durability. It must meet all the operating requirements in the whole engine operating range. At the engine operation in unsteady conditions, the highest intensity of wear takes place in the cylinder- ringpiston assembly.

\section{Assumptions to the study}

The issue concerning thermal loads of a piston in a diesel engine during startup is not widely presented in the literature. A piston during operation of a combustion engine gets in direct contact with the working medium, the temperature and the pressure of which changes periodically over a wide range. The maximum values of the cycle temperatures in Diesel engines can reach $1800 \div 2300 \mathrm{~K}$, and the average cycle temperatures can even exceed $900 \mathrm{~K}$. High temperatures and hard operating conditions require the pistons to maintain particular strength parameters not only within the given temperature ranges. It is important for a piston to meet its requirements over the whole operating range already from the moment of the engine start. A piston operates at different operating conditions. Increased wear in the cylinder- ringpiston assembly shows how vital a stage the engine startup is, particularly at low temperatures.

Therefore, in the authors' opinion it seems important to get to know the phenomena characteristic of the piston thermal load during startup of a diesel engine at low temperatures. In a direct injection diesel engine, there is a specially shaped combustion chamber in the piston head. A discharge of almost all the heat delivered together with the fuel takes place in that space, which significantly increases its thermal load. It seems necessary to settle the following research problems/issues:

1. Determining of the piston thermal fields distribution depending on the diesel engine starting temperature.

2. Analysis of the piston thermal fields distribution at different starting temperatures, and thus determining of its thermal loads.

3. Comparison of the piston thermal fields distribution in a steady condition and in unsteady conditions of heat exchange.

The presented objective is accomplished based on:

- starting tests in the low temperature test chamber in the engine laboratory of the Faculty of Automotive Vehicles Operation at Technical University of Szczecin with the use of testing and research equipment available to the author,

- modelling and simulation of piston thermal loads of the 359 engine with numerical methods by means of the COSMOS/Works 4.0 computer software that uses the finite element method.

The paper presents piston thermal loads of the 359 engine during its starting at negative ambient temperatures. One may think that at the state of an unsteady heat exchange, the initial temperature during startup of a diesel engine influences the to zarówno ustalonych, jak i przejściowych (nieustalonych). Potrzebne jest to do prawidłowego projektowania tłoka i wykonania go z takich materiałów, aby jego eksploatacja była prawidłowa. Tłok nie może ulec przedwczesnemu zużyciu ani tym bardziej uszkodzeniu, a w ogólnym rozumieniu - powodować nieprawidłową pracę silnika. Musi charakteryzować się dużą wytrzymałością na obciążenia mechaniczne i cieplne oraz niezawodnością i trwałością. Spełniać musi wszystkie wymogi eksploatacyjne w całym zakresie pracy silnika. Przy pracy silnika w warunkach nieustalonych największa intensywność zużycia istnieje w zespole cylinder-pierścienie tłokowe-tłok.

\section{Założenia artykułu}

Problematyka dotycząca obciążeń cieplnych tłoka silnika wysokoprężnego podczas rozruchu nie jest obszernie przedstawiana $\mathrm{w}$ literaturze. Tłok podczas pracy silnika spalinowego styka się bezpośrednio z czynnikiem roboczym, którego temperatura oraz ciśnienie zmieniają się okresowo w szerokim zakresie. Maksymalne wartości temperatury obiegu w silnikach o zapłonie samoczynnym mogą osiągnąć 1800-2300 K, a średnie temperatury obiegu moga przekraczać nawet $900 \mathrm{~K}$. Wysokie temperatury oraz trudne warunki pracy powodują, że tłoki powinny charakteryzować się szczególnymi parametrami wytrzymałościowymi materiałów i to nie tylko w podanych zakresach temperaturowych. Ważne jest, aby tłok spełniał te wymagania podczas całej pracy i to już od momentu uruchomienia silnika. Tłok pracuje w różnych warunkach eksploatacyjnych. $\mathrm{O}$ tym, jak istotnym etapem jest rozruch silnika, szczególnie w niskich temperaturach, świadczy zwiększone zużycie w układzie cylinder-pierścienie tłokowe-tłok.

Dlatego, zdaniem autorów, ważne wydaje się poznanie zjawisk towarzyszących obciążeniu cieplnemu tłoka podczas rozruchu silnika wysokoprężnego w niskich temperaturach. W silniku o zapłonie samoczynnym o wtrysku bezpośrednim, w denku tłoka znajduje się odpowiednio ukształtowana komora spalania. W przestrzeni tej odbywa się wywiązywanie prawie całej ilości ciepła doprowadzonego z paliwem, co znacznie zwiększa jej obciążenie cieplne. Wydaje się konieczne rozstrzygnięcie następujących problemów badawczych:

1. Wyznaczenie rozkładu pól temperatur tłoka w zależności od temperatury rozruchu silnika o zapłonie samoczynnym.

2. Przeprowadzenie analizy rozkładu pól temperatur tłoka w różnych temperaturach rozruchu, a tym samym określenie jego obciążeń cieplnych.

3. Porównanie rozkładów pól temperatur tłoka w stanie ustalonym i w stanach nieustalonych wymiany ciepła.

Przedstawione cele realizowane są w oparciu o:

- badania rozruchowe w komorze niskich temperatur w laboratorium silnikowym Katedry Eksploatacji Pojazdów Samochodowych Politechniki Szczecińskiej przy użyciu dostępnej aparatury kontrolno-badawczej,

- modelowanie i symulacje obciążeń cieplnych tłoka silnika 359 metodami numerycznymi za pomoca programu komputerowego COSMOS/Works 4.0 wykorzystującego metodę elementów skończonych (MES). 
distribution of the piston thermal fields in a way different than in a steady condition.

\section{Object of testing}

The tests consisted in two stages. The first stage covered the starting tests of a diesel engine. These tests were carried out on the 359 engine. It is an engine made by a Polish manufacturer (FSC Starachowice), commonly used in STAR 200 trucks and off-road vehicles such as STAR 266 and STAR 244. The 359 engine is a six-cylinder, in-line vertical diesel engine with direct fuel injection.

The piston of the 359 engine is a piston of the "autothermatic" type. It has got embedded steel stabilising inserts at the height of the piston pin. Application of such steel inserts reduces thermal expansion of the piston as the piston warms up and reduces changes of its shape in the direction perpendicular to the pin axis. The piston is made of aluminium alloy (Al-Si eutectic alloy), and it also has a cast iron load-bearing insert, embedded with "Al-fin" method under the upper sealing ring. The piston head is of open type of toroidal shape, where there is a combustion chamber off-set in relation to the piston axis by $6 \mathrm{~mm}$.

\section{Starting tests of the 359 engine}

Preparation to the starting test consisted in cooling of the engine together with fuel and starting battery in the low temperature test chamber. The test was carried out for four different ambient temperatures: 258, 263, 268 and $273 \mathrm{~K}$. After the set temperature had been reached in the measuring points, the engine together with fuel and battery was subject to stabilisation for approximately 12 hours.

The starting characteristic of the 359 engine has been shown in Fig. 1, depending on the ambient temperature. The following have been presented in the starting characteristic:

- time of occurrence of first ignitions depending on the ambient temperature,
W pracy przedstawiono obciążenia cieplne tłoka silnika 359 podczas jego rozruchu w ujemnych temperaturach otoczenia.

Można sądzić, że w stanie nieustalonej wymiany ciepła, temperatura początkowa podczas rozruchu silnika wysokoprężnego wpływa na rozkład pól temperatur tłoka w inny sposób niż w stanie ustalonym.

\section{Obiekt badań}

Badania obejmowały dwa etapy. Pierwszy etap stanowiły badania rozruchowe silnika o zapłonie samoczynnym. Ze względu na dostępność i możliwości techniczne badania te przeprowadzano na silniku 359. Jest to silnik produkcji krajowej (FSC Starachowice), powszechnie używany w pojazdach samochodów ciężarowych STAR 200 oraz terenowych STAR 266 i STAR 244. Silnik 359 jest sześciocylindrowym, rzędowym, pionowym silnikiem wysokoprężnym o bezpośrednim wtrysku paliwa.

Tłok silnika 359 jest typu ,,autothermatic”. Posiada wtopione stalowe wkładki stabilizujące na wysokości sworznia tłokowego. Zastosowanie tych wkładek stalowych zmniejsza rozszerzalność cieplną tłoka w miarę jego nagrzania i ogranicza zmiany jego kształtu w kierunku prostopadłym do osi sworznia. Tłok wykonany jest ze stopu aluminiowego (stop eutektyczny Al-Si) i ma także żeliwną wkładkę nośną, zatapianą metodą „Al-fin” pod górny pierścień uszczelniający. Denko tłoka jest typu otwartego o kształcie toroidalnym. W denku znajduje się komora spalania przesunięta względem osi tłoka o $6 \mathrm{~mm}$.

\section{Badania rozruchowe silnika 359}

Przygotowanie do próby rozruchu polegało na wychłodzeniu w komorze niskich temperatur silnika wraz z paliwem i akumulatorami rozruchowymi. Badania realizowano dla czterech różnych temperatur otoczenia: 258, 263, 268 i 273 K. Po osiagnięciu zadanej temperatury w punktach pomiarowych silnik wraz z paliwem i akumulatorami poddawano stabilizacji przez około 12 godzin. Charakterystykę rozruchową silnika 359 w zależności od temperatury otoczenia

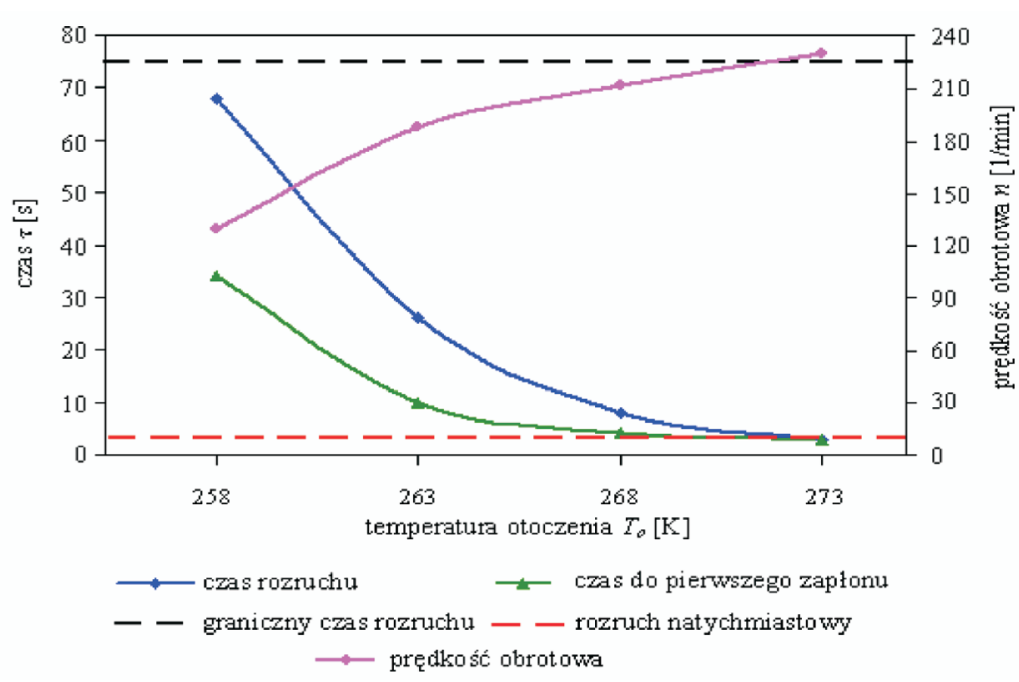

pokazano na rys. 1 i 2 .

$\mathrm{Na}$ charakterystyce rozruchowej przedstawiono:

- czas wystąpienia pierwszych zapłonów w zależności od temperatury otoczenia,

- niezbędny czas obracania rozrusznikiem do chwili uzyskania samodzielnej pracy silnika w zależności od temperatury otoczenia,

- zależność średniej prędkości obrotowej od temperatury otoczenia,

- graniczny czas rozruchu, $\tau_{\mathrm{gr}}=75 \mathrm{~s}$.

\section{Symulacja obciążeń cieplnych tloka silnika 359 podczas rozruchu}

Przepływ ciepła jest zjawiskiem przebiegającym w czasie. O jego intensywności decydują warunki brzegowe oraz stan cieplny badanego obiektu w chwili początkowej. Do określenia pola temperatury w ciele stałym

Fig. 1. Starting characteristic of the 359 engine

Rys. 1. Charakterystyka rozruchowa silnika 359 
- essential time for the starter revolutions until the operation of the engine is obtained,

- depending on the ambient temperature,

- dependence of the average engine speed on the ambient temperature,

- limit starting time, $\tau_{\mathrm{gr}}=75 \mathrm{~s}$.

\section{Simulation of thermal loads of the 356 engine piston during startup}

The heat flow is a phenomenon that takes place in time. Its intensity is decided by the boundary conditions and the thermal state of an object under testing at the initial moment. A differential equation of unsteady thermal conductivity is used for the determining of the thermal field in a solid body. This equation, in the three-dimensional Cartesian reference system, in an anisotropic solid body with internal heat sources with the efficiency qv, has got the form of:

$$
\begin{aligned}
& \mathrm{c}_{\mathrm{p}} \cdot \rho \cdot \frac{\partial \mathrm{T}}{\partial \tau}=\frac{\partial}{\partial \mathrm{x}}\left(\lambda_{\mathrm{x}} \cdot \frac{\lambda \mathrm{T}}{\partial \mathrm{x}}\right)+ \\
& +\frac{\partial}{\partial \mathrm{y}}\left(\lambda_{\mathrm{y}} \cdot \frac{\partial \mathrm{T}}{\partial \mathrm{y}}\right)+\frac{\partial}{\partial \mathrm{z}}\left(\lambda_{\mathrm{z}} \cdot \frac{\partial \mathrm{T}}{\partial \mathrm{z}}\right)+\mathrm{q}_{\mathrm{v}}
\end{aligned}
$$

for $\mathrm{T}=\mathrm{T}(\mathrm{x}, \mathrm{y}, \mathrm{z}, \tau), \mathrm{c}_{\mathrm{p}}=\mathrm{const}, \rho=\mathrm{const}$ and $\lambda_{\mathrm{x}}, \lambda_{\mathrm{y}}, \lambda_{\mathrm{z}}=$ = const,

where: $c_{p}-$ specific heat $[\mathrm{J} / \mathrm{kg} \cdot \mathrm{K}], \rho-$ material density $\left[\mathrm{kg} / \mathrm{m}^{3}\right], \mathrm{T}$ - temperature $[\mathrm{K}], \tau-$ time $[\mathrm{s}], \lambda_{\mathrm{x}}-$ thermal conductivity in the $\mathrm{x}$ direction $[\mathrm{W} / \mathrm{m} \cdot \mathrm{K}], \lambda_{\mathrm{y}}$ - thermal conductivity in the $y$ direction $[\mathrm{W} / \mathrm{m} \cdot \mathrm{K}], \lambda_{\mathrm{z}}^{\mathrm{y}}-$ thermal conductivity in the $\mathrm{z}$ direction $[\mathrm{W} / \mathrm{m} \cdot \mathrm{K}], \mathrm{q}_{\mathrm{v}}$ - volumetric efficiency of a heat source $\left[\mathrm{W} / \mathrm{m}^{3}\right]$.

This equation gives the most general difference between the temperature, the time and the space coordinates that must be met for any thermal field in a solid body. In order to determine the thermal field in the model of the tested object, this equation must be supplemented with the conditions of the solution uniqueness. In order to carry out modelling and simulation of thermal loads of the piston in the COSMOS/ Works 4.0 software, the uniqueness conditions have been determined $[1,3,4]$. The algorithm of proceeding for solution of the heat flow through the tested object with the application of the COSMOS/Works 4.0 system [2] has been presented in the form of a block diagram in Fig. 3.

\section{Analysis of thermal loads of the 359 engine piston during startup}

Example of distribution of the 359 engine piston thermal field in a plane parallel to the axis of the piston pin during startup at the ambient temperature of $258 \mathrm{~K}$ before occurrence of first ignitions is presented in Fig. 4.

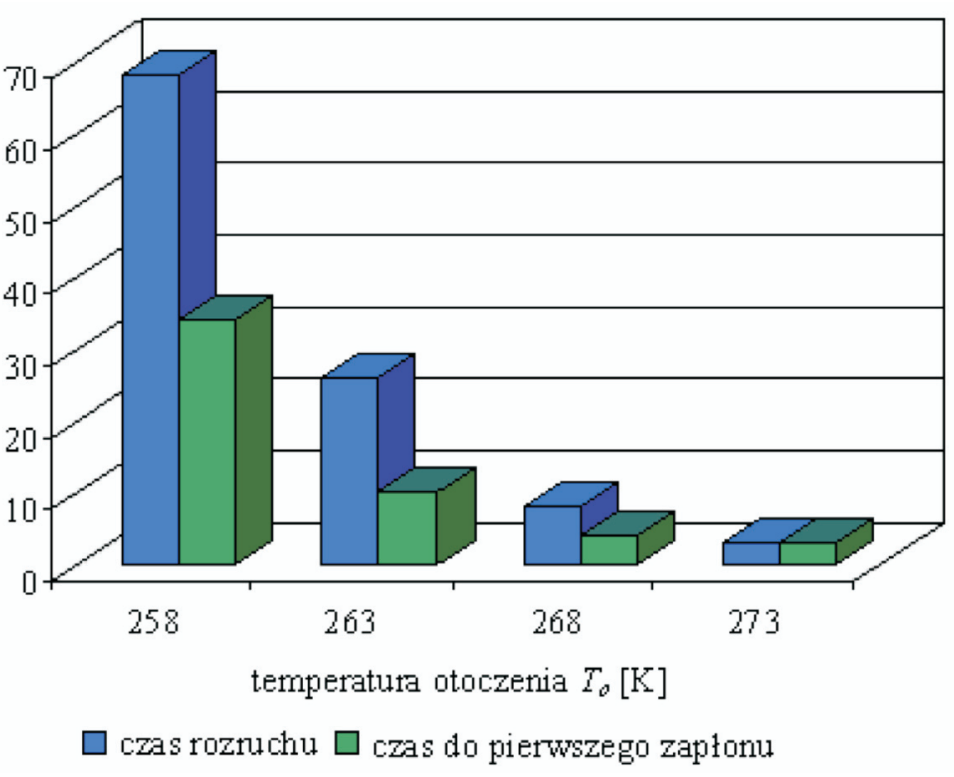

Fig. 2. Dependence of the 359 engine starting time on the ambient temperature Rys. 2. Zależność czasu rozruchu silnika 359 od temperatury otoczenia

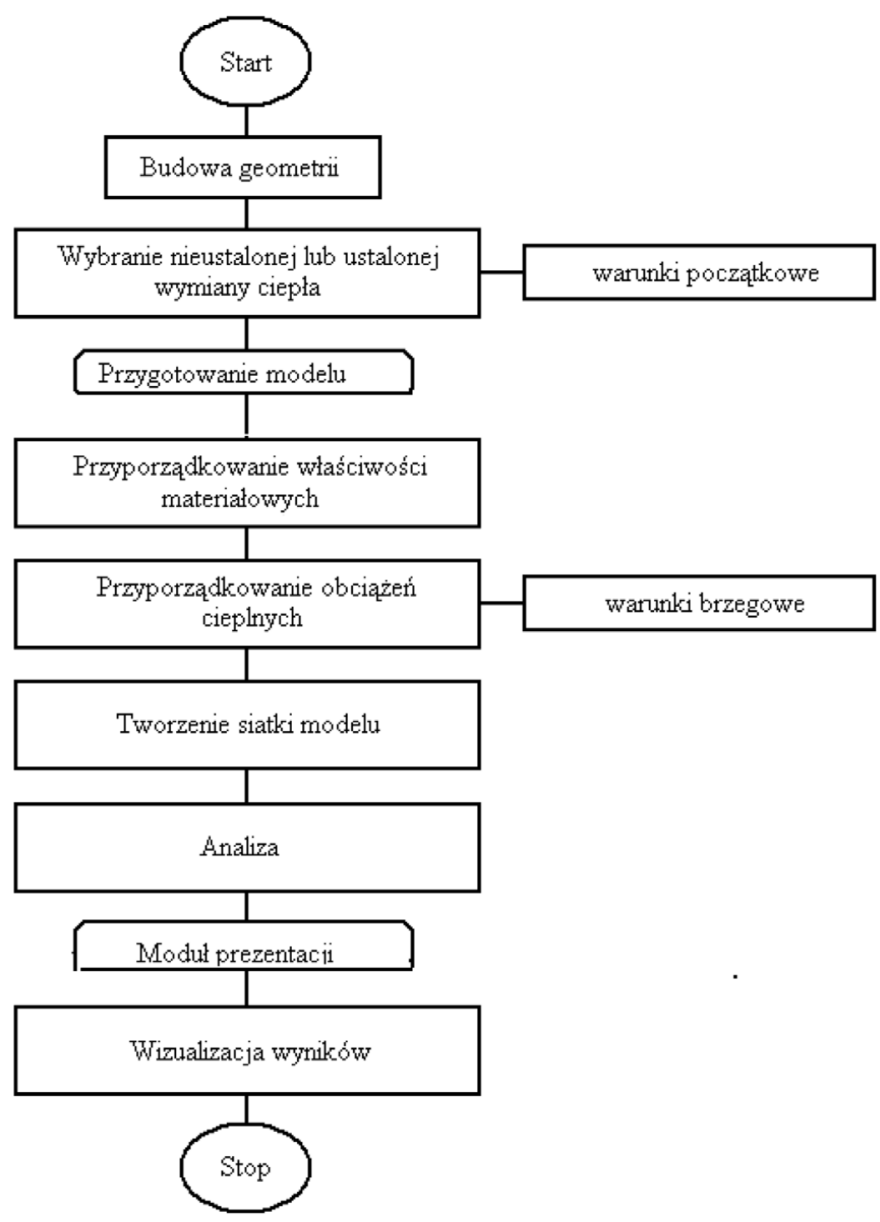

Fig. 3. Block diagram of the algorithm of calculations with the finite element method COSMOS/Works 4.0

Rys. 3. Schemat blokowy algorytmu obliczeń metodq elementów skończonych COSMOS/Works 4.0 
TLOK359-258:: Thermal Time Step : 34 Units: Kelvin

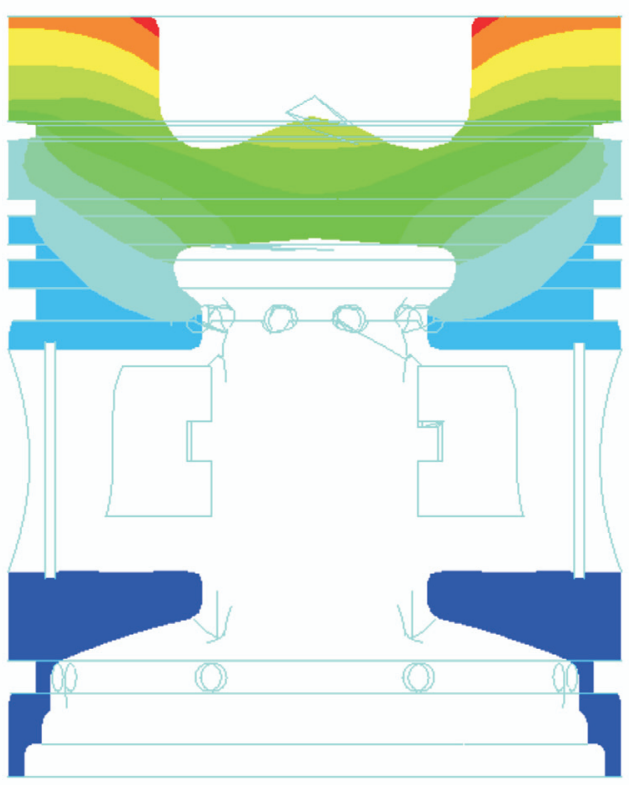

Fig. 4. Distribution of the 359 engine piston thermal field in the plane parallel to the axis of the piston pin during startup at the ambient temperature of $258 \mathrm{~K}$ after $34 \mathrm{~s}$

Rys. 4. Rozkład pola temperatury tłoka silnika 359 w płaszczyźnie równoległej do osi sworznia tlokowego podczas rozruchu w temperaturze otoczenia $258 \mathrm{~K}$ po $34 \mathrm{~s}$

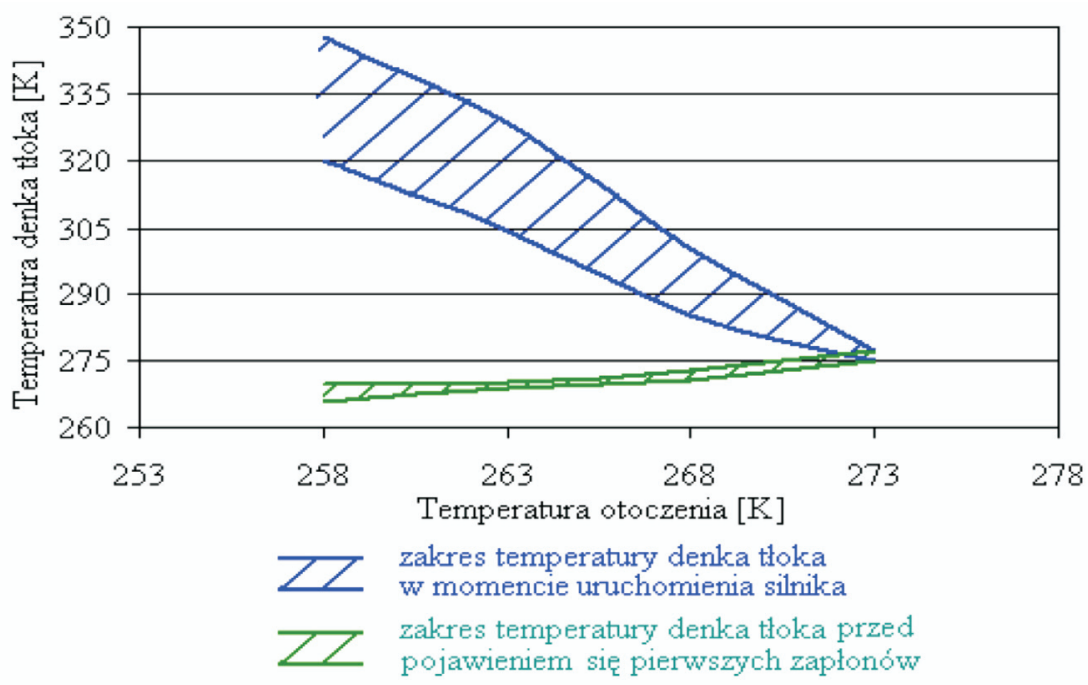

Fig. 5. Range of the piston head temperature variations depending on the ambient temperature Rys. 5. Zakres zmian temperatury denka ttoka w zależności od temperatury otoczenia

\section{Conclusions}

The executed simulation tests have confirmed the thesis that the initial temperature at the state of unsteady heat exchange significantly influences the distribution of the thermal fields of the piston and it is different than in the state of steady heat exchange. On the basis of the executed simulation tests and distribution of temperatures one can formulate the following conclusions:

1. Thermal load of the piston during the engine startup is closely related to the values of the ambient temperature, at which startup of the engine took place. służy równanie różniczkowe nieustalonego przewodzenia ciepła. Równanie to w przestrzennym, kartezjańskim układzie odniesienia, w anizotropowym ciele stałym z wewnętrznymi źródłami ciepła o wydajności qv, ma postać (1)

dla $\mathrm{T}=\mathrm{T}(\mathrm{x}, \mathrm{y}, \mathrm{z}, \tau), \mathrm{c}_{\mathrm{p}}=\mathrm{const}, \rho=\mathrm{const}$ and $\lambda_{x}, \lambda_{y}, \lambda_{z}=$ const,

gdzie: $\mathrm{c}_{\mathrm{p}}-$ ciepło właściwe $[\mathrm{J} / \mathrm{kg} \cdot \mathrm{K}]$, $\rho$-gęstość materiału $\left[\mathrm{kg} / \mathrm{m}^{3}\right], \mathrm{T}$ - temperatura $[\mathrm{K}], \tau-$ czas $[\mathrm{s}], \lambda_{\mathrm{x}}-$ współczynnik przewodzenia ciepła w kierunku $\mathrm{x}$ [W/m·K], $\lambda_{\mathrm{y}}-$ współczynnik przewodzenia ciepła w kierunku y $[\mathrm{W} / \mathrm{m} \cdot \mathrm{K}]$, $\lambda$ - współczynnik przewodzenia ciepła w kierunku z [W/m·K], $\mathrm{q}_{\mathrm{v}}$ - wydajność objętościowa źródła ciepła $\left[\mathrm{W} / \mathrm{m}^{3}\right]$.

W celu przeprowadzenia modelowania i symulacji obciążeń cieplnych tłoka w programie COSMOS/Works 4.0 określono warunki jednoznaczności [1, $3,4]$. Algorytm postępowania rozwiązania przepływu ciepła przez badany obiekt przy zastosowaniu systemu COSMOS/ Works 4.0 [2] przedstawiony jest na schemacie blokowym na rys. 3 .

\section{Analiza obciążeń cieplnych tloka silnika 359 podczas rozruchu}

Przykład rozkładu pola temperatury tłoka silnika w płaszczyźnie równoległej do osi sworznia tłokowego podczas rozruchu w temperaturze otoczenia 258 $\mathrm{K}$, przed pojawieniem się pierwszych zapłonów, przedstawiono na rys. 4 .

\section{Wnioski}

Wykonane badania symulacyjne potwierdziły tezę, że w stanie nieustalonej wymiany ciepła, temperatura początkowa w sposób istotny wpływa na rozkład pól temperatur tłoka i jest on odmienny niż w stanie ustalonej wymiany ciepła. Na podstawie przeprowadzonych badań symulacyjnych i otrzymanych na ich podstawie rozkładów temperatur można

sformułować następujące wnioski:

1. Obciążenie cieplne tłoka podczas rozruchu silnika jest ściśle związane z wartościami temperatury otoczenia, w której przeprowadzano uruchamianie silnika.

2. Rozkład pól temperatur tłoka w przypadku stanu ustalonego jest odmienny niż w stanach nieustalonych podczas rozruchu silnika.

3. Temperatura denka tłoka przed pojawieniem się pierwszych zapłonów jest tym większa, im większa jest temperatura otoczenia, przy której następuje rozruch silnika. Przy temperaturze początkowej $258 \mathrm{~K}$ średnia 
2. The distribution of the thermal fields of the piston is different in the case of a steady state as opposed to the unsteady states during the engine startup.

3. The higher the ambient temperature at which the startup of the engine takes place the higher the temperature of the piston head before the occurrence of first ignitions. At the initial temperature of $258 \mathrm{~K}$, the average value of the piston head is $268 \mathrm{~K}$, and at the initial temperature of $273 \mathrm{~K}$, the average temperature of the piston head is $276 \mathrm{~K}$.

4. The lower is the ambient temperature at which the starting of the engine takes place the higher the temperature of the piston head at the moment the engine starts. At the initial temperature of $258 \mathrm{~K}$, the average temperature of the piston head is $335 \mathrm{~K}$, and at the initial temperature of $268 \mathrm{~K}$, the average temperature of the piston head is only $293 \mathrm{~K}$.

5. The lower the ambient temperature the higher the difference in temperatures between the hottest and the coldest layer of the piston both before the occurrence of first ignitions and at the moment of the engine startup.

6. The highest temperature increments take place in the upper parts of the piston (piston head and piston crown). For the ambient temperature of $258 \mathrm{~K}$, these increments are the highest and they reach up to $90 \mathrm{~K}$.

7. In the plane perpendicular to the axis of the piston pin, there is an asymmetry of the temperature distribution - the piston temperature in its upper parts, towards the off-set of the combustion chamber is higher and ranges from 3 up to $12 \mathrm{~K}$.

8. The first upper ring groove is characterised by high temperature difference between the upper and the lower groove surface in comparison to other ring grooves. The difference in the temperature reaches even up to $15 \mathrm{~K}$ at the initial temperature of $258 \mathrm{~K}$ and, at the initial temperature of 268, the difference is lower and it is $9 \mathrm{~K}$.

9. When comparing the ranges of the piston head temperatures before the occurrence of first ignitions and at the moment of the engine startup - depending on the initial temperature - one can determine the ambient temperature, at which the engine startup is immediate. wartość temperatury denka tłoka wynosi $268 \mathrm{~K}$, zaś przy temperaturze początkowej $273 \mathrm{~K}$ średnia temperatura denka tłoka wynosi $276 \mathrm{~K}$ (rys. 5).

4. Temperatura denka tłoka $\mathrm{w}$ momencie podjęcia przez silnik samodzielnej pracy jest tym wyższa, im niższa jest temperatura otoczenia, przy której następuje rozruch silnika. Przy temperaturze początkowej $258 \mathrm{~K}$ średnia wartość temperatury denka tłoka wynosi $335 \mathrm{~K}$, zaś przy temperaturze początkowej $268 \mathrm{~K}$ średnia temperatura denka tłoka wynosi tylko $293 \mathrm{~K}$ (rys. 5).

5. Różnica temperatury między najcieplejszą a najchłodniejszą warstwą tłoka jest tym większa, im mniejsza jest temperatura otoczenia, zarówno przed pojawieniem się pierwszych zapłonów oraz w momencie uruchomienia silnika.

6. Największe przyrosty temperatury występują w górnych cześciach tłoka (denku tłoka i koronie). Dla temperatury otoczenia $258 \mathrm{~K}$, przyrosty te są największe i wynoszą nawet $90 \mathrm{~K}$.

7. W płaszczyźnie prostopadłej do osi sworznia tłokowego występuje asymetria rozkładu temperatury - temperatura tłoka w jego górnych częściach, w kierunku przesunięcia komory spalania, jest wyższa i zawiera się w granicach $3-12 \mathrm{~K}$

8. Pierwszy górny rowek pierścieniowy $\mathrm{w}$ porównaniu $\mathrm{z}$ pozostałymi rowkami pierścieniowymi charakteryzuje się dużą różnicą temperatury pomiędzy górną a dolną powierzchnią rowka. Różnica temperatury dochodzi nawet do $15 \mathrm{~K}$, przy temperaturze początkowej $258 \mathrm{~K}$, przy temperaturze początkowej $268 \mathrm{~K}$ różnica ta jest mniejsza i wynosi $9 \mathrm{~K}$.

9. Porównując zakresy temperatury denka tłoka przed pojawieniem się pierwszych zapłonów i w momencie uruchomienia silnika, w zależności od temperatury początkowej, można wyznaczyć temperaturę otoczenia, przy której rozruch silnika jest natychmiastowy.

Artykut recenzowany.

\section{Bibliography/Literatura}

[1] Budzik G., Jaskólski J.: Obciążenia cieplne tłoków silników spalinowych. Oficyna Wydawnicza Politechniki Rzeszowskiej. Rzeszów 2004.

[2] COSMOS/Works User's Guide. Structural Research and Analysis Corporation. Los Angeles 1997.

[3] Jaskólski J., Budzik G.: Przegląd zastosowań metody elementów skończonych do wyznaczania pól temperatury w tłoku. Czasopismo Techniczne 2M/1999, Wydawnictwo Politechniki Krakowskiej. Kraków 1999.

[4] Kwaśniowski S., Sroka Z., Zabłocki W. : Modelowanie obciążeń cieplnych w elementach silników spalinowych. Oficyna Wydawnicza Politechniki Wrocławskiej. Wrocław 1999.
Prof. Janusz Mysłowski, DSc, MEng - Professor in the Faculty of Mechanical Engineering at Szczecin University of Technology.

Prof. dr hab. inż. Janusz Mystowski - profesor na Wydziale Inżynierii Mechanicznej i Mechatroniki Politechniki Szczecińskiej.

Mr Krzysztof Talaga, PhD, MEng-doctor in the Faculty of Mechanical Engineering at Szczecin University of Technology.

Dr inż. Krzysztof Talaga - adiunkt na Wydziale Inżynierii Mechanicznej i Mechatroniki Politechniki Szczecińskiej. 